\title{
Evidence does not support the conclusion that Hexarthra intermedia (Rotifera, Monogononta, Flosculariaceae) causes mortality in Bosmina longirostris (Cladocera, Diplostraca, Branchiopoda)
}

\author{
Robert L. Wallace1,* and Elizabeth J. Walsh² \\ ${ }^{1}$ Department of Biology, Ripon College, Ripon, WI, 54971, USA. \\ 2 Department of Biological Sciences, 500 W. University Ave., University of Texas at El Paso, El Paso, TX, \\ 79968, USA. \\ * Corresponding author: wallacer@ripon.edu
}

Received: 05/03/18 Accepted: 27/09/18

\begin{abstract}
Evidence does not support the conclusion that Hexarthra intermedia (Rotifera, Monogononta, Flosculariaceae) causes mortality in Bosmina longirostris (Cladocera, Diplostraca, Branchiopoda)

Based on observations of preserved samples, Jaramillo-Londoño \& Pinto-Coelho (2010) describe a putative ecological relationship between the rotifer Hexarthra intermedia and the cladoceran Bosmina longirostris as a fusion of parasitism and interference competition. They argue that $H$. intermedia enter the filtering chamber of $B$. longirostris allowing the rotifer to exploit food collected by Bosmina, while simultaneously receiving protection from predators. In addition, they surmise that the result of this interaction can lead to death of Bosmina. We posit two simpler explanations for their observations. (1) Presence of $H$. intermedia in the cladoceran's filtering chamber is an artifact of the collection methods. (2) Statistical correlations between the population levels of these two species simply means that the environment was suitable for their growth. Thus until additional evidence corroborates their findings, the simpler explanations should prevail.
\end{abstract}

Key words: freshwater, inference competition, María Rosa Miracle, parasitism, zooplankton

\section{RESUMEN}

La evidencia no soporta la conclusión de que Hexarthra intermedia (Rotifera, Monogononta, Flosculariaceae) es la causa de la mortalidad de Bosmina longirostris (Cladocera, Diplostraca, Branchiopoda)

Jaramillo-Londoño y Pinto-Coelho (2010) describen una relación ecológica putativa entre el rotífero Hexarthra intermedia y el cladócero Bosmina longirostris como una fusión de parasitismo y competencia por interferencia con base en observaciones hechas en muestras preservadas. Se argumenta que $\mathrm{H}$. intermedia ingresa a la cámara de filtración de $\mathrm{B}$. longirostris permitiendo al rotifero aprovechar los alimentos recolectados por Bosmina, y al mismo tiempo recibir protección de los depredadores. El resultado de esta interacción puede llevar a la muerte de Bosmina. Postulamos explicaciones más simples para sus observaciones. (1) La presencia de $\mathrm{H}$. intermedia en la cámara de filtrado del cladócero es un resultado del método de recolección del mismo. (2) Las correlaciones estadisticas entre los niveles de población de estas dos especies simplemente significan que el ambiente era adecuado para su crecimiento. Por lo tanto, hasta que la evidencia adicional corrobore sus hallazgos, las explicaciones más simples deben prevalecer.

Palabras clave: agua dulce, competencia por interferencia, María Rosa Miracle, parasitismo, zooplancton 


\section{Preface}

This paper, along with the others appearing in this volume, lauds the meticulous research of Prof. Dr. María Rosa Miracle. During her distinguished career spanning five decades she greatly expanded our understanding of the ecological niche of rotifers (Miracle, 1974; Carmona et al., 1989; Esparcia et al., 1989; Vicente \& Miracle, 1992; Miracle et al., 1995; Armengol \& Miracle, 1999; Miracle et al., 2007; Miracle et al., 2014; Onandia et al., 2015). Her thorough work should serve as a guide to other investigations. Here we emphasize the care that must be taken in studies that explore interactions of rotifers with other zooplankton species and in drawing inferences that expand the rotiferan niche.

\section{INTRODUCTION}

Understanding community structure and population dynamics of zooplankton, as well as the details of their biotic interactions, requires studies across several scales, both spatial and temporal. At large spatial scales studies have examined zooplankton in many freshwaters systems. These kinds of studies inform us about how edaphic conditions influence zooplankton community composition and development (Balayla et al., 2010; Obertegger et al., 2010; Pinel-Alloul \& Mimouni, 2013; Hiltunen et al., 2015; Gozdziejewska et al., 2016). Study at small spatial scales revealed the patchiness of the plankton (Lehman \& Scavia 1982; Schuler et al., 2017), as well microhabitat preferences among species (Walsh, 1995; Van de Meutter et al., 2004; Kuczynska-Kippen \& Nagengast, 2006). Research across long-term temporal scales (years to decades) has uncovered information about the dynamics of populations yielding information about when species appear and disappear seasonally, yearly, or longer (Herzig, 1987; Hampton et al., 2006; Hampton \& Schindler, 2006; Muirhead et al., 2006; Smith et al., 2009; Obertegger et al., 2011; Francis et al., 2014). At intermediate timescales (weeks to months) investigations have provided details about individual species or a suite of similar species (Ruttner-Kolisko, 1977; Fey et al., 2010; Sastri et al., 2014; McMeans et al., 2015). At the smallest timescales (minutes to days) we have learned some of the details of how individual species interact with each other and their abiotic environment (Burns \& Gilbert, 1986; Kirk \& Gilbert, 1988; Kirk \& Gilbert 1990; Hampton \&
Gilbert, 2001; Diéguez \& Gilbert 2011; Sarma et al., 2011). Thus, from the collective research across these scales several influential techniques and concepts have been established including, for example, the egg ratio technique, the microbial loop, community hysteresis and compensatory dynamics in zooplankton communities, feeding specializations, and other unique behaviors. Of course, the weight of these concepts has been amplified by careful observation and critical analysis. More importantly, these concepts have been confirmed by repeated observations and experimentation.

Edmondson's egg ratio technique has been used to analyze the population dynamics of a variety of zooplankton populations (Edmondson, 1960; Edmondson et al., 1962; Edmondson, 1968; Balayla \& Moss, 2003). Other researchers subsequently modified the technique; the collective outcome was an important tool for study of in situ population dynamics (Caswell, 1972; Paloheimo, 1974). Elucidation of the microbial loop gave new insight into energy flow and nutrients cycling in aquatic systems (Azam et al., 1983; Stockner \& Porter, 1988; Arndt, 1993; Jürgens \& Jeppesen, 2000; Azémar et al., 2006; Kissman et al., 2017). Careful examination of zooplankton community structure during perturbations has led to a better understanding of both hysteresis and compensatory dynamics (e.g., Fischer et al., 2001; Frost et al., 2006; Pace et al., 2013). Several accounts have documented the concept of feeding specialization in zooplankton. Actually understanding feeding specialization in these taxa has been an important area of research for many years (Wallace et al., 2006 and references therein). Undeniably, the field is replete with studies 
that have explored this subject, either in field or laboratory settings (e.g., Edmondson, 1965; Bodgan \& Gilbert, 1984; Stemberger \& Gilbert, 1987; Williamson \& Vanderploeg, 1988; Brett \& Müller-Navarra, 1997; Jackson \& Thomas Kiørboe, 2004; Noyon \& Froneman, 2014; Onandia et al., 2015; Benedetti et al., 2016).

Research also has documented the occurrence of interesting trophic interactions among protists and micrometazoans (i.e., cladocerans, fungi, and rotifers). Here we note four examples. (1) Ciliates and heliozoans engulf whole rotifers (Wallace $e t$ al., 2015). (2) Soil and aquatic fungi feed as saprophytic parasites on rotifers and nematodes (Barron, 1980; Robb \& Barron, 1982; Barron \& Szijarto, 1984; Fialkowska \& Pajdak-Stós, 2018). (3) Rotifer species of Dicranophorus and Proales are carrion feeders, cleaning out the carapaces of dead cladocerans and copepods, as well as the bodies of freshwater oligochaetes (Nogrady et al., 1993; Wallace et al., 2006). (4) Rotifers also are predatory on cladocerans. The rotifer Dicranophorus isothes Harring \& Myers, 1928 is a predator, feeding strictly on cladocerans such as Alona, Chydorus, and small Moina. Harring \& Myers (1928) provide a brief description of this rotifer's

Table 1. An analysis of the argument presented by Jaramillo-Londoño and Pinto-Coelho (2010) regarding interactions between Hexarthra intermedia and Bosmina longirostris. Un análisis del argumento presentado por Jaramillo-Londoño y Pinto-Coelho (2010) sobre las interacciones entre Hexarthra intermedia y Bosmina longirostris.

\begin{tabular}{|c|c|c|}
\hline $\begin{array}{l}\text { Our comment number } \\
\text { (Original Pagination) }\end{array}$ & Synopsis of the authors' points & Our remarks \\
\hline $1(962)$ & $\begin{array}{l}\text { Samples were preserved in } 4 \% \text { formalin } \\
\text { and transported back to the laboratory } \\
\text { for analysis. }\end{array}$ & $\begin{array}{l}\text { No chemical agents were added to } \\
\text { reduce potential for osmotic shock. No } \\
\text { anesthetization was attempted. Preserved } \\
\text { animals can become agitated during } \\
\text { transportation. }\end{array}$ \\
\hline $2(963)$ & $\begin{array}{l}\leq 4 \text { well-preserved Hexarthra were } \\
\text { present inside empty carapaces of } \\
\text { Bosmina; see Fig. } 3 \mathrm{~B} \text {. }\end{array}$ & $\begin{array}{l}\text { Distortion is common during } \\
\text { preservation of cladocerans (e.g., the } \\
\text { body pulls away from the carapace). } \\
\text { Hexarthra may then enter an empty } \\
\text { carapace. }\end{array}$ \\
\hline $3(963)$ & $\begin{array}{l}\text { Hexarthra density was positively } \\
\text { correlated with both density of Bosmina } \\
\text { and with their exuviae, suggesting } \\
\text { existence of a recurrent association and } \\
\text { also the possible impact of Hexarthra } \\
\text { on Bosmina death rates. }\end{array}$ & $\begin{array}{l}\text { Statistical correlation does not } \\
\text { necessarily mean causation. An } \\
\text { alternative explanation that could be } \\
\text { proposed is that both species are } \\
\text { responding to favorable conditions (e.g., } \\
\text { availability of food, temperature, and few } \\
\text { predators). }\end{array}$ \\
\hline $4(964)$ & $\begin{array}{l}\text { Hexarthra has malleoramate trophi, } \\
\text { prefers food sizes of }<6 \mu \mathrm{m} \text {. It moves } \\
\text { with darting a motion that results in } \\
\text { Bosmina becoming prey. }\end{array}$ & $\begin{array}{l}\text { These two sentences comprise a 3-part } \\
\text { syllogism. The logical fallacy that this } \\
\text { argument presents is discussed in the } \\
\text { body of our text. }\end{array}$ \\
\hline $5(964)$ & $\begin{array}{l}\text { Hexarthra in the filtering chamber of } \\
\text { Bosmina suggests a fusion of parasitism } \\
\text { with interference competition. }\end{array}$ & $\begin{array}{l}\text { No evidence has been provided to } \\
\text { document live Hexarthra entering the } \\
\text { thoracic region of Bosmina where } \\
\text { suspension feeding takes place. }\end{array}$ \\
\hline $6(964)$ & $\begin{array}{l}\text { Hexarthra causes noticeable damage to } \\
\text { the "hosts", this relationship also } \\
\text { approaches some form of parasitism } \\
\text { (Fig. 5). }\end{array}$ & $\begin{array}{l}\text { No evidence has been provided that } \\
\text { qualifies as noticeable damage having } \\
\text { been inflicted on the Bosmina. }\end{array}$ \\
\hline
\end{tabular}


predatory activities. NB: A permanent slide deposited in The Academy of Natural Sciences of Philadelphia [ANSP] (now The Academy of Natural Sciences of Drexel University) and pictured in Jersabek et al. (2003) depicts a putative predatory event between $D$. isothes and Alona sp. (F.J. Myers is credited with the preparation of this slide [Specimen Preparation ANSP 912]). Also the rotifer Asplanchnopus multiceps (Schrank, 1793) is known to feed on cladocerans and rotifers (Nandini \& Sarma, 2005). Other unusual feeding habits exhibited by rotifers are reviewed in Wallace et al. (2006).

However, another novel trophic pathway has been reported that requires additional analysis. Jaramillo-Londoño \& Pinto-Coelho (2010) report that the rotifer Hexarthra intermedia (Wiszniewski, 1929) [hereafter Hexarthra] interact with the limnetic cladoceran Bosmina longirostris (O.F. Muller, 1785) [hereafter Bosmina], ultimately resulting in mortal damage being inflicted on the cladoceran. As of this writing we are aware of $>12$ papers that have cited this paper, but most only reference it without commenting on its findings (e.g., Santos-Wisniewski et al., 2011; Jaramillo-Londoño \& Aguirre-Ramírez, 2012; Pauwels et al., 2014; Kotov \& Fuentes-Reines, 2015; Ergönül et al., 2016; Gürbüzer et al., 2017). Because observation regarding Hexarthra impacting Bosmina influences our understanding of the freshwater food web, in general, and specifically the niche and trophic dynamics of rotifers, we believe that the methods and conclusions of this paper need to be re-examined carefully. In the spirit of Miracle's careful attention to detail, we review the methodology, results, and conclusions of Jaramillo-Londoño \& Pinto-Coelho (2010) and offer alternative explanations to their observations.

\section{EVIDENCE AND A REINTERPRETATION}

The research of Jaramillo-Londoño \& Pinto-Coelho (2010) was based on preserved zooplankton samples taken from the Vargem das Flores Reservoir, located ca. $20 \mathrm{~km}$ southwest of Belo Horizonte, Minas Gerais, Brazil. The unusual conclusion proposed in this paper is that Hexarthra exploit a new trophic-ecological niche axis (page 964) representing ".. a fusion of parasitism with interference competition." The implied logic is that the food for Hexarthra in this reservoir is composed mainly of small coccoid shaped cells, which provide only some of the dietary needs for this rotifer. These authors hypothesized that Hexarthra is able to find additional nutritional resources by intruding into the filtering chamber of Bosmina, thereby exploiting resources (algal particles filtered by Bosmi$n a$ and residing in its filtering chamber). In addition, while in the filtering chamber Hexarthra also receives shelter from predators. We highlight six instances where the evidence provided is insufficient to support the authors' conclusions (Table 1). In presenting our analysis (below) we quote the authors.

Point 1 (Page 962). "All samples were preserved in $4 \%$ formalin for further laboratory processing." The statement gives no indication whether their preservation methods followed the standard protocol for preserving plankton samples as described by Downing \& Rigler (1984). As these researchers point out, unless care is taken cladocerans can become distorted (ballooning). Ballooning often results in a forward flexure of the abdomen, which exposes the brood chamber and permits loss of developing young (see Haney $\&$ Hall, 1973). Thus poor preservation may be the cause of the animal's flexing seen in Fig. 1B. The result of distortion of the Bosmina specimens during fixation may be, in part, responsible for Hexarthra ending up in the filtering chamber of Bosmina in the preserved samples.

Point 2 (Page 963). "It was common to detect up to four well-preserved individuals of $H$. intermedia inside empty bodies of $B$. longirostris." It is well known by researchers who study Hexarthra that they frequently adhere to one another and to other materials in preserved samples sometimes even the arms adhere to the bodies of other rotifers (S. Nandini, S.S.S. Sarma, \& R. Shiel, pers. comm.; EJW, pers. obs.). This fact can account for the connection of Hexarthra to live Bosmina that were killed during preservation, as well as to their exuviae. With sufficient agitation during transport to the laboratory the spine-bearing arms of Hexarthra could easily become entangled with Bosmina. 
Point 3 (Page 963). "The density of $H$. intermedia was positively correlated with the density of $B$. longirostris containing $H$. intermedia ..., and with the occurrence of carapaces of $B$. longirostris containing $H$. intermedia ... (Fig. 4)." If the carapaces are exuviae, then the occurrence of Hexarthra within them may well be simply circumstantial. "These results and correlations suggest not only the existence of a recurrent association between these two species, but also the possible impact of $H$. intermedia intrusions on death rates of $B$. longirostris." A positive correlation between two factors does not mean cause and effect. Given that both species are suspension feeders, a correlation of population sizes probably indicates that they are responding to favorable conditions in the habitat. That is, there is adequate food and probably also favorable temperature and few predators. This association does not confirm cause and effect of an "... impact of $H$. intermedia intrusions on death rates of B. longirostris."

Point 4 (Page 964). One paragraph, comprising two sentences, essentially constitutes a three-part categorical syllogism, which may be presented as follows.

1. "Hexarthra intermedia has a mastax with malleoramate trophi ... , and prefers [to consume] particles smaller than $6 \mu \mathrm{m} . . . . "$

2. "Its darting movements [of Hexarthra] offer some protection against predation ..., and"

3. "so [due to the darting movements of Hexarthra] B. longirostris becomes an easy prey to capture ...."

Unfortunately, the elements in this syllogism are not logically connected. The fact that Hexarthra has malleoramate trophi has nothing to do with the fact that this rotifer can move by darting movements (jumps). While frequent jumps by Hexarthra may increase encounters with other large planktonic organisms, they do not make Bosmina an easy prey. Indeed the darting movements or jumps of Hexarthra (and other rotifers such as Polyarthra) are escape movements that move the animals away from disturbances in the water, not toward them (Kirk \& Gilbert, 1988; Kak \& Rao, 1998; Hochberg \& Ablak Gurbuz, 2008; Hochberg et al., 2017). Thus, the rapid evasive movements of Hexarthra appear to protect it from being swept into the branchial chambers of cladocerans.

The statement that “... B. longirostris becomes an easy prey to capture ...." [by Hexarthra] is puzzling. The typical diet of Hexarthra is known to comprise particles in the size range of bacteria and algae $(\leq 6 \mu \mathrm{m})$ (Bouvy et al., 1994; Pagano et al., 1998). These limits in food size are a function of morphology of its malleoramate trophi, which are used to process food by a grinding action (Fontaneto \& De Smet, 2015). Additionally, the mastax (with trophi) lies deep enough inside Hexarthra's body to prevent the animal from protruding its trophi through the mouth to grasp individual prey items. That sort of predatory behavior is seen in raptorial, predatory rotifers such as Asplanchna and Asplanchnopus (Wallace et al., 2015; H. Segers, pers. comm.). Thus, Hexarthra is simply not mechanically suited to feed on large cladoceran prey. To do so would require extruding its trophi from its mouth, cutting thorough the exoskeleton, and then rending tissues for ingestion.

Point 5 (Page 964). The authors note that “... intrusion of individuals of $H$. intermedia in the filtering chamber of Bosmina is not a trivial feature, ... ." The photomicrographs of Hexarthra and Bosmina (Figs. 1B-D) do not support this assertion. They show the following: Fig. 1B one Hexarthra near the exit of the brood chamber and another attached to the legs; Fig. 1C - one Hexarthra in an empty carapace of Bosmina; and Fig. 1D - a small Bosmina in juxtaposition with a carapace from a larger animal, with one, perhaps two, Hexarthra also adhering to the carapace. The positioning could be a result of preservation artifacts as discussed above.

Heeg \& Rayner (1988) also have described close associations among zooplankton in preserved samples. They reported Hexarthra mira (Hudson, 1871) forming short, conspecific chains of between two and seven individuals. In some chains Trichocerca chattoni (Beauchamp, 1907) were also present. They also reported that both $H$. mira and $T$. chattoni attached to B. longirostris. These observations are similar to those made by Jaramillo-Londoño and Pinto-Chelho (2010), and thus we conclude that their observations also are misinterpretations of preservation artifacts. 
Point 6 (Page 964). The authors state “... intrusion of individuals of $H$. intermedia in the filtering chamber of Bosmina is not a trivial feature, since it reveals signs of a new ecological relationship that could be seen as a fusion of parasitism with interference competition. ... ... Nevertheless, since it causes noticeable damage to the "hosts", this relationship also approaches some form of parasitism (Fig. 5)." The authors offer no documentation of Hexarthra inflicting damage to Bosmina. Actually, studies of rotifer-cladoceran interactions have documented the reverse; rotifers that have been swept into the branchial chamber of large cladocerans are often damaged (sometimes lethally) (Fradkin, 1995). We conclude that the relationship conceptualized in Fig. 5 is not warranted.

\section{DISCUSSION}

The possibility for the novel feeding dynamic of Hexarthra outlined by Jaramillo-Londoño \& Pinto-Coelho (2010) is intriguing, but premature. Indeed simpler interpretations of their observations are warranted. The observation that the population size of Hexarthra was correlated to that of Bosmina is a misinterpretation of statistical correlation; it does not support an argument for cause and effect. Photomicrographs of Hexarthra in contact with Bosmina and even inside empty carapaces could be artifacts of the collection methods and the fact that Hexarthra adheres to materials in preserving fluids. Of course, we know that cladocerans and rotifers do interact by exploitative and/or interference competition with cladocerans possessing the competitive advantage (Gilbert, 1985; 1989), and that anostracans can consume Hexarthra sp. (Starkweather, 2005). However, the evidence provided by Jaramillo-Londoño \& Pinto-Coelho (2010) reports no competitive advantage of Bosmina over Hexarthra. We suggest that additional research should be undertaken to explore the potential for competition between these taxa.

We agree with the author's final conclusion: "The final question regarding the effects of $H$. intermedia on $B$. longirostris is the potential impact of this interaction on Bosmina populations. Resolving this question will require a more exhaustive study." We suggest that such an exhaustive study requires the systematic application of the criteria outlined by Platt (1964) for scientific problems. This means formulating multiple working hypotheses that are testable, refutable, and repeatable. In this case, the study must include meticulous observations of live Hexarthra in close association with live Bosmi$n a$. Thus, until further evidence is obtained the answer to the question as to whether a new trophic interaction occurs between these two species is no.

\section{ACKNOWLEDGEMENTS}

We thank Hendrik Segers who read an early version of this manuscript and S. Nandini, S. S. S. Sarma, and R. Shiel who confirmed our observations on the adherence of Hexarthra to cladocerans and other materials in preserved samples We also thank two anonymous reviewers for their helpful comments. The National Science Foundation (USA) provided, in part, funding for this research (DEB-1257068 (E. J. Walsh) and DEB-1257116 (R. L. Wallace)).

\section{REFERENCES}

ARMENGOL, X. \& M. R. MIRACLE. 1999. Zooplankton communities in doline lakes and pools, in relation to some bathymetric parameters and physical and chemical variables. Journal of Plankton Research, 21:2245-2261. DOI: $10.1093 /$ plankt/21.12.2245

ARNDT, H. 1993. Rotifers as predators on components of the microbial web (bacteria, heterotrophic flagellates, ciliates) - a review. Hydrobiologia, 255/256:231-246. DOI: 10.1007/ BF00025844

AZAM, F., T. FENCHEL, J. G. FIELD, J. S. GRAY, L. A. MEYER-REIL \& F. THINGSTAD. 1983. The ecological role of water-column microbes in the sea. Marine Ecology-Progress Series, 10:257-263. DOI: 10.3354/meps010257

AZÉMAR, F., S. BOULÊTREAU, M. LIONARD, K. MUYLAERT, W. VYVERMAN, P. MEIRE \& M. TACKX. 2006. Looking for general trends in trophic interactions among 
estuarine micro- and mesozooplankton. Journal of Plankton Research, 29:1135-i147. DOI: 10.1093/plankt/fb1072

BALAYLA, D. J. \& B. MOSS. 2003. Spatial patterns and population dynamics of plant-associated microcrustacea (Cladocera) in an English shallow lake (Little Mere, Cheshire). Aquatic Ecology, 37:417-435. DOI: 10.1023/ B:AECO.0000007045.85315.dc

BALAYLA, D., T. L. LAURIDSEN, M. SØNDERGAARD \& E. JEPPESEN. 2010. Larger zooplankton in Danish lakes after cold winters: are winter fish kills of importance? Hydrobiologia, 646:159-172. DOI: 10.1007/ s10750-010-0164-4

BARRON, G. L. 1980. Nematophagous fungi: a new Harposporium from soil. Canadian Journal of Botany, 58:447-450. DOI: 10.1139/b80-052

BARRON, G. L. \& E. SZIJARTO. 1984. Fungal parasites of bdelloid rotifers: A new Phialophora. Mycologia, 76:1107-1110. DOI: $10.2307 / 3793026$

BENEDETTI, F., S. GASPARINI \& S.-D. AYATA. 2016. Identifying copepod functional groups from species functional traits. Journal of Plankton Research, 38:159-166. DOI: 10.1093/plankt/fbv096

BODGAN, K. \& J. J. GILBERT. 1984. Body size and food size in freshwater zooplankton. PNAS, 81:6427-6431. DOI: 10.1073/pnas.81.20.6427

BOUVY, M., R. ARFI, D. GUIRAL, M. PAGANO \& L. SAINT-JEAN. 1994. Role of bacteria as food for zooplankton in a eutrophic tropical pond (Ivory Coast). Netherlands Journal of Aquatic Ecology, 28:167-174. DOI: 10.1007/BF02333987

BRETT, M. \& D. MÜLLER-NAVARRA. 1997. The role of highly unsaturated fatty acids in aquatic foodweb processes. Freshwater Biology, 38:483-499. DOI: 10.1046/j.1365-2427. 1997.00220.x

BURNS, C. W. \& J. J. GILBERT. 1986. Direct observations of the mechanisms of interference between Daphnia and Keratella cochlearis. Limnology and Oceanography, 31:859-866. DOI: 10.4319/lo.1986.31.4.0859

CARMONA, M. J., M. SERRA \& M. R. MIRACLE. 1989. Protein patterns in rotifers: the timing of aging. Hydrobiologia, 186/187:
325-330. DOI: 10.1007/BF00048928

CASWELL, H. 1972. On instantaneous and finite birth rates. Limnology and Oceanography, 17:787-791. DOI: 10.4319/lo.1972.17.5.0787 DIÉGUEZ, M. C. \& J. J. GILBERT. 2011. Daphnia-rotifer interactions in Patagonian communities. Hydrobiologia, 662:189-195. DOI: 10.1007/s10750-010-0495-1

DOWNING, J. A. \& F. H. RIGLER. 1984. A manual on methods for the assessment of secondary productivity in fresh waters. $2^{\text {nd }}$ ed. Blackwell Scientific, Oxford, U.K., Oxford, UK. ISBN 13: 978-0632006168

EDMONDSON, W. T. 1960. Reproductive rates of rotifers in natural populations. Memorie Istituto Italiano Idrobiologia, 12:21-77.

EDMONDSON, W. T. 1965. Reproductive rate of planktonic rotifers as related to food and temperature in nature. Ecological Monographs, 35: 61-111. DOI: 10..2307/1942218

EDMONDSON, W. T. 1968. A graphical model for evaluating the use of the egg ratio for measuring birth and death rates. Oecologia, 1:1-37. DOI: $10.1007 / \mathrm{BF} 00377252$

EDMONDSON, W. T., G. W. COMITA \& G. C. ANDERSON. 1962. Reproductive rate of copepods in nature and its relation to phytoplankton population. Ecology, 43:625-634. DOI: $10.2307 / 1933452$

ERGÖNÜL, M. B., S. ERDOGAN, A. ALTINDAG \& S. ATASAGUN. 2016. Rotifera and Cladocera fauna of several lakes from the Central Anatolia, Marmara, and Western Black Sea regions of Turkey. Turkish Journal of Zoology, 40:141-146. DOI: 10.3906/zoo-1503-22

ESPARCIA, A., M. R. MIRACLE \& M. SERRA. 1989. Brachionus plicatilis tolerance to low oxygen concentrations. Hydrobiologia, 186/187:331-337. DOI: 10.1007/978-94-0090465-1_40

FEY, S. B., Z. A. MAYER, S. C. DAVIS \& K. L. COTTINGHAM. 2010. Zooplankton grazing of Gloeotrichia echinulata and associated life history consequences. Journal of Plankton Research, 32:337-1347. DOI: 10.1093/plankt/ fbq052

FIALKOWSKA, E. \& A. PAJDAK-STÓS. 2018. Temperature-dependence of predator-prey dynamics in interactions between the predatory 
fungus Lecophagus sp. and its prey L. inermis rotifers. Microbial Ecology, 75:400-406. DOI: 10.1007/s00248-017-1060-5

FISCHER, J. M., T. M. FROST \& A. R. IVES. 2001. Compensatory dynamics in zooplankton community responses to acidification: measurement and mechanisms. Ecological Applications, 11:1060-1072. DOI: 10.2307/3061012

FONTANETO, D. \& W. H. DE SMET. 2015. Rotifera. Pages 217-300 in A. Schmidt-Rhaesa, editor. Handbook of Zoology: Gastrotricha, Cycloneuralia and Gnathifera. Volume 3: Gastrotricha and Gnathifera. De Gruyter, Berlin. ISBN 9783110273816

FRADKIN, S. C., 1995. Effects of interference and exploitative competition from large-bodied cladocerans on rotifer community structure. Hydrobiologia, 313:387-393. DOI: 10.1007/BF00025975

FRANCIS, T. B., E. M. WOLKOVICH, M. D. SCHEUERELL, S. L. KATZ, E. E. HOLMES \& S. E. HAMPTON. 2014. Shifting regimes and changing interactions in the Lake Washington, U.S.A., plankton community from 1962-1994. PLoS ONE, 9:e110363. DOI: 10.1371/journal.pone.0110363

FROST, T. M., J. M. FISCHER, J. L. KLUG, S. E. ARNOTT \& P. K. MONTZ. 2006. Trajectories of zooplankton recovery in the Little Rock Lake whole-lake acidification experiment. Ecological Applications, 16:353-367. DOI: $10.1890 / 04-1800$

GILBERT, J. J. 1985. Competition between rotifers and Daphnia. Ecology, 66:1943-1950. DOI: $10.2307 / 2937390$

GILBERT, J. J. 1989. Competitive interactions between the rotifer Synchaeta oblonga and the cladoceran Scapholeberis kingi Sars. Hydrobiologia, 186/187:75-80. DOI: 10.1007/978-94009-0465-1_10

GOZDZIEJEWSKA, A., K. GLINSKA-LEWCZUK, K. OBOLEWSKI, M. GRZYBOWSKI, R. KUJAWA, S. LEW \& M. GRABOWSKA. 2016. Effects of lateral connectivity on zooplankton community structure in floodplain lakes. Hydrobiologia, 774:7-21. DOI: 10.1007/s10750-016-2724-8 GÜRBÜZER, P., Ö. BUYURGAN, Ç. TEKATLI \& A. ALTINDAĞ. 2017. Species diversity and community structure of zooplankton in three different types of water body within the Sakarya River Basin, Turkey. Turkish Journal of Zoology, 41:848-859. DOI: 10.3906/zoo1606-41

HANEY, J. F. \& D. J. HALL. 1973. Sugar-coated Daphnia: A preservation technique for Cladocera. Limnology and Oceanography, 18:331-333. DOI: 10.4319/lo.1973.18.2.0331

HAMPTON, S. E. \& J. J. GILBERT. 2001. Observations of insect predation on rotifers. Hydrobiologia, 446/447:115-121. DOI: 10.1023/A:1017543121353

HAMPTON, S. E., M. D. SCHEUERELL \& D. E. SCHINDLER. 2006. Coalescence in the Lake Washington story: Interaction strengths in a planktonic food web. Limnology and Oceanography, 51:2042-2051. DOI: 10.4319/lo.2006.51.5.2042

HAMPTON, S. E. \& D. E. SCHINDLER. 2006. Empirical evaluation of observation scale effects in community time series. Oikos, 113:424-439. DOI: $10.1111 / \mathrm{j} .2006 .0030-1299.14643 . x$

HARRING, H. K. \& F. J. MYERS. 1928. The rotifer fauna of Wisconsin, IV. The Dicranophorinae. Transactions of the Wisconsin Academy of Sciences, Arts and Letters, 23:667-808.

HEEG, J. \& N. A. RAYNER. 1988. Inter- and intra-specific associations as some possible predator avoidance and energy conservation strategies in planktonic rotifers. Journal of the Limnological Society of Southern Africa, 14:87-92. DOI 10.1080/03779699.1988. 9632843

HERZIG, A. 1987. The analysis of planktonic rotifer populations: a plea for long-term investigations. Hydrobiologia, 147:163-180. DOI: 10.1007/978-94-009-4059-8_22

HILTUNEN, M., U. STRAN̄DBERG, S. J. TAIPALE \& P. KANKAALA. 2015. Taxonomic identity and phytoplankton diet affect fatty acid composition of zooplankton in large lakes with differing dissolved organic carbon concentration. Limnology and Oceanography, 60:303-317. DOI: 10.1002/lno. 10028

HOCHBERG, R. \& O. ABLAK GURBUZ. 2008. Comparative morphology of the somatic musculature in species of Hexarthra and Polyarthra (Rotifera, Monogononta): Its 
function in appendage movement and escape behavior. Zoologischer Anzeiger, 247:233-248. DOI: 10.1016/j.jcz.2008.01.002

HOCHBERG, R., H. YANG \& J. MOORE. 2017. The ultrastructure of escape organs: setose arms and cross-striated muscles in Hexarthra mira (Rotifera: Gnesiotrocha: Flosculariaceae). Zoomorphology, 136:159-173. DOI: 10.1007/s00435-016-0339-2

JACKSON, G. A. \& T. THOMAS KIØRBOE. 2004. Zooplankton use of chemodetection to find and eat particles. Marine Ecology Progress Series, 269:153-162. DOI: 10.3354/meps 269153

JARAMILLO-LONDOÑO, J. C. \& R. M. PINTO-COELHO. 2010. Interaction between Hexarthra intermedia (Rotifera) and Bosmina longirostris (Cladocera): a case of opportunistic nutrition or interference competition? Journal of Plankton Research, 32: 961-966. DOI: $10.1093 /$ plankt/fbq020

JARAMILLO-LONDOÑO, J. C. \& N. J. AGUIRRE-RAMÍREZ. 2012. Cambios espacio-temporales del plancton en la Ciénaga de Ayapel (Córdoba-Colombia), durante la época de menor nivel del agua. Caldasia, 34:213-226. https:// search.proquest.com/docview/1677410263? accountid $=9525$

JERSABEK, C. D., H. SEGERS \& B. J. DINGMANN. 2003. The Frank J. Myers Rotifer Collection at The Academy of Natural Sciences: The whole collection in digital images. The Academy of Natural Sciences of Philadelphia, Special Publication 20. DOI: 10.1007/s10750-005-4110-9

JÜRGENS, K. \& E. JEPPESEN. 2000. The impact of metazooplankton on the structure of the microbial food web in a shallow, hypertrophic lake. Journal of Plankton Research, 22:1047-1070. DOI: 10.1093/plankt/22.6.1047

KAK, A. \& T. R. RAO. 1998. Does the evasive behavior of Hexarthra influence its competition with cladocerans? Hydrobiologia, 387/388: 409-419. DOI: 10.1023/A:1017055013639

KIRK, K. L. \& J. J. GILBERT. 1988. Escape behavior of Polyarthra in response to artificial flow stimuli. Bulletin of Marine Science, 43:551-560.

KIRK, K. L. \& J. J. GILBERT. 1990. Suspended clay and the population dynamics of planktonic rotifers and cladocerans. Ecology, 71:1741-1755. DOI: $10.2307 / 1937582$

KISSMAN, C. E. H., C. E., WILLIAMSON, K. C. ROSE, \& J. E. SAROS. 2017. Nutrients associated with terrestrial dissolved organic matter drive changes in zooplankton: phytoplankton biomass ratios in an alpine lake. Freshwater Biology, 62:40-51. DOI: 10.1111/fwb. 12847

KOTOV, A. A. \& J. M. FUENTES-REINES. 2015. An annotated checklist of the Cladocera (Crustacea: Branchiopoda) of Colombia. Zootaxa, 4044:493-510. DOI: 10.11646/zootaxa.4044.4.2

KUCZYNSKA-KIPPEN, N. M., \& B. NAGENGAST. 2006. The influence of the spatial structure of hydromacrophytes and differentiating habitat on the structure of rotifer and cladoceran communities. Hydrobiologia, 559:203-212. DOI: $10.1007 / \mathrm{s} 10750-005-0867-0$

LEHMAN, J. T. \& D. SCAVIA. 1982. Microscale patchiness of nutrients in plankton communities. Science, 216:729-730. DOI: 10.1126/science. 216.4547 .729

MCMEANS, B. C., A.-M. KOUSSOROPLIS \& M. J. KAINZ. 2015. Effects of seasonal seston and temperature changes on lake zooplankton fatty acids. Limnology and Oceanography, 60:573-583. DOI: 10.1002/1no.10041

MIRACLE, M. R. 1974. Niche structure in freshwater zooplankton: a principal components approach. Ecology, 55:1306-1316. DOI: $10.2307 / 1935458$

MIRACLE, M. R., M. T. ALFONSO, E. VICENTE \& W. KOSTE. 1995. Rotifers of spring pools in the coastal marshland of Albufera of Valencia Natural Park. Limnetica, 11:39-47.

MIRACLE, M. R., M. T. ALFONSO \& E. VICENTE. 2007. Fish and nutrient enrichment effects on rotifers in a Mediterranean shallow lake: a mesocosm experiment. Hydrobiologia, 593:77-94. DOI: 10.1007/s10750-007-9071-8 MIRACLE, M. R., E. VICENTE, S. S. S. SARMA \& S. NANDINI. 2014. Planktonic rotifer feeding in hypertrophic conditions. International Review of Hydrobiology, 99:141-150. DOI: 10.1002/iroh.201301714

MUIRHEAD, J. R., J. EJSMONT-KARABIN \& 
H. J. MacISAAC. 2006. Quantifying rotifer species richness in temperate lakes. Freshwater Biology, 51:1696-1709. DOI: 10.1111/j. 1365-2427.2006.01614.x

NANDINI, S. \& S. S. S. SARMA. 2005. Life history characteristics of Asplanchnopus multiceps (Rotifera) fed rotifer and cladoceran prey. Hydrobiologia, 546:491-501. DOI: 10.1007/s10750-005-4291-2

NOGRADY, T., R. L. WALLACE \& T. W. SNELL. 1993. Rotifera: Volume 1 Biology, Ecology and Systematics. SPB Academic Publishing bv, The Hague. ISBN 90-5103-080-0

NOYON, M. \& P. W. FRONEMAN. 2014. The diet of the calanoid copepod, Pseudodiaptomus hessei, in a permanently open southern African estuary inferred from fatty acid analyses. Journal of Plankton Research, 36:1153-1158. DOI: 10.1093/plankt/fbu037

OBERTEGGER, U., B. THALER \& G. FLAIM. 2010. Rotifer species richness along an altitudinal gradient in the Alps. Global Ecology and Biogeography, 19:895-904. DOI: 10.1111/j.1466-8238.2010.00556.x

OBERTEGGER, U., H. A. SMITH, G. FLAIM \& R. L. WALLACE. 2011. Using the guild ratio to characterize pelagic rotifer communities. Hydrobiologia, 662:157-162. DOI: 10.1007/ s10750-010-0491-5

ONANDIA, G., J. D. DIAS \& M. R. MIRACLE. 2015. Zooplankton grazing on natural algae and bacteria under hypertrophic conditions. Limnetica, 34:541-56

PACE, M. L., S. R. CARPENTER, R. A. JOHNSON, \& J. T. KURTZWEIL. 2013. Zooplankton provide early warnings of a regime shift in a whole lake manipulation. Limnology and Oceanography, 58: 525-532. DOI: 10.4319/lo. 2013.58.2.0525

PAGANO, M., L. SAINT-JEAN, R. ARFI, M. BOUVY \& D. GUIRAL. 1998. Zooplankton food limitation and grazing in a eutrophic brackish-water tropical pond (Côte d'Ivoire, West Africa). Hydrobiologia, 390:83-89. DOI: $10.1023 / \mathrm{A}: 1003561821745$

PALOHEIMO, J. E. 1974. Calculation of instantaneous birth rates. Limnology and Oceanography, 19:692-694. DOI: 10.4319/lo.1974.19.4.0692
PAUWELS, K., L. De MEESTER, H. MICHELS, E. JEPPESEN \& E. DECAESTECKER. 2014. An evolutionary perspective on the resistance of Daphnia to the epizoic rotifer Brachionus rubens. Freshwater Biology, 59:1247-1256. DOI: 10.1111/fwb.12344

PINEL-ALLOUL, B. \& E.-A. MIMOUNI. 2013. Are cladoceran diversity and community structure linked to spatial heterogeneity in urban landscapes and pond environments? Hydrobiologia, 715:195-212. DOI: 10.1007/s 10750013-1484-y

PLATT, J. R. 1964. Strong inference. Science, 146: 347-353. DOI: 10.1126/science.146.3642.347

ROBB, E. J. \& G. L. BARRON. 1982. Nature's ballistic missile. Science, 218:1221-1222. DOI: $10.1126 /$ science. 218.4578 .1221

RUTTNER-KOLISKO, A. 1977. The effect of the microsporid Plistophora asperospora on Conochilus unicornis in Lunzer Untersee (LUS). Archiv für Hydrobiologie, 8:135-137. SANTOS-WISNIEWSKI, M. J. D., T. MATSUMURA-TUNDISI, N. F. NEGREIROS, L. C. D. SILVA, R. M. D. SANTOS \& O. ROCHA. 2011. Present knowledge on Cladocera (Crustacea, Branchiopoda) diversity of freshwaters in Minas Gerais State. Biota Neotropica, 11:287-301. DOI: 10.1590/S1676-06032011000300024

SARMA, S. S. S., R. A. LARA RESENDIZ \& N. SARMA. 2011. Morphometric and demographic responses of brachionid prey (Brachionus calyciflorus Pallas and Plationus macracanthus (Daday) in the presence of different densities of the predator Asplanchna brightwellii (Rotifera: Asplanchnidae). Hydrobiologia, 622:179-187. DOI: $10.1007 / \mathrm{s} 10750-010-0494-2$

SASTRI, A. R., J. GAUTHIET, P. JUNEAU \& B. E. BEISNER. 2014. Biomass and productivity responses of zooplankton communities to experimental thermocline deepening. Limnology and Oceanography, 59:1-16. DOI: 10.4319/1o.2014.59.1.0001

SCHULER, M. S., J. M.CHASE, \& T. M. KNIGHT. 2017. Habitat patch size alters the importance of dispersal for species diversity in an experimental freshwater community. Ecology and Evolution, 7:5774-5783. DOI: 10.1002/ece 3.2858

SMITH, H. A., J. EJSMONT-KARABIN, T. M. 
HESS \& R. L. WALLACE. 2009. Paradox of planktonic rotifers: similar structure but unique trajectories in communities of the Great Masurian Lakes (Poland). Verhandlungen Internationale Vereinigung Limnologie, 30:951-956. DOI: 10.1080/03680770.2009.11902278

STARKWEATHER, P. L. 2005. Susceptability of ephemeral pool Hexarthra to predation by fairy shrimp Branchinecta mackini: can predation drive local extinction? Hydrobiologia, 546:503-508. DOI: 10.1007/1-4020-4408-9_51

STEMBERGER, R. S. \& J. J. GILBERT. 1987. Rotifer threshold food concentrations and the size-efficiency hypothesis. Ecology, 68:181-187. DOI: 10.2307/1938818

STOCKNER, J. G. \& K. G. PORTER. 1988. Microbial food webs in freshwater planktonic ecosystems. Pages 69-83 in S. R. Carpenter, editor. Complex Interactions in Lake Communities. Springer-Verlag. DOI: 10.1007/978-14612-3838-6_5

VAN DE MEUTTTER, F., R. STOKS, \& L. DE MEESTER. 2004. Behavioral linkage of pelagic prey and littoral predators: microhabitat selection by Daphnia induced by damsel- fly larvae. Oikos, 107: 265-272. DOI: 10.1111/j.0030-1299.2004.13221.x

VICENTE, E. \& M. R. MIRACLE. 1992. The coastal lagoon Albufera de Valencia: an ecosystem under stress. Limnetica, 8:87-100.

WALLACE, R. L., T. W. SNELL, C. RICCI \& T. NOGRADY. 2006. Rotifera. Volume 1: Biology, Ecology and Systematics (2nd edition). Backhuys Publishers, Leiden. ISBN 90-5782-178-8

WALLACE, R. L., T. W. SNELL \& H. A. SMITH. 2015. Phylum Rotifera. Pages 225-271 in J. H. Thorp and D. C. Rogers, editors. Thorp and Covich's Freshwater Invertebrates. Elsevier, Waltham, MA. ISBN 9780123850263

WALSH, E. J. 1995. Habitat-specific predation susceptibilities of a littoral rotifer to two invertebrate predators. Hydrobiologia, 313:205-211. DOI: 10.1007/BF00025952

WILLIAMSON, C. E. \& H. A. VANDERPLOEG. 1988. Predatory suspension-feeding in Diaptomus: prey defenses and the avoidance of cannibalism. Bulletin of Marine Science, 43:561-572.

Con el apoyo de:
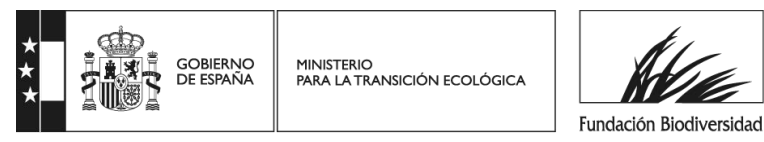